Assistant Vice-President in 1949, and Vice-President in 1951, which position he still holds. He is registered as a B.C.R.F., and is a member of the C.I.F.

Mr. Buckland graduated from the U.B.C. in 1936, and registered with the Association in 1940. He was with Bloedel, Stewart and Welch Ltd., from 1936-42, and with Canadian Forest Products Ltd., Englewood Division, as Resident Engineer, from 1942 to 1944 , when he went into private practice as a Consulting Engineer and Forester. $\mathrm{He}$ is still in the consulting field. Mr. Buckland is also a member of the C.I.F.

\title{
S.A.F. Elects New OfFicers and Fellows
}

DeWitt Nelson, Sacramento, California, was elected December 3 as president of the Society of American Foresters. He succeeds Elwood L. Demmon, of Asheville, N.C.

Mr. Nelson, who is director of the California Department of Natural Resources, was vice president of the Society during the biennium 1954-1955.

George A. Garratt of New Haven, Conn., dean of the Yale University School of Forestry, was elected vice president of the Society.

\section{Council Members}

The following foresters were elected to the Council for two-year terms 1956-1957: B. E. Allen, Philip A. Briegleb, C. Huxley Coulter, Stanley G. Fontanna, Maurice K. Goddard, Edwin F. Heacox, Joseph S. Illick, J. Herbert Stone and Henry J. Vaux.

\section{Fellows Elected}

In addition to the foregoing officers, the following nine Fellows were elected. Election to the grade of Fellow is conferred only for outstanding achievement in forestry: Reed W. Bailey, John S. Boyce, Dwight B. Demeritt, Samuel B. Detwiler, Stanley G. Fontanna, J. Alfred Hall, Frank H. Kaufert, Frederick P. Keen and Gordon D. Marckworth.

\section{Newly Registered Foresters in B.C.}

The Council of the Association of British Columbia Foresters announces that the following candidates have completed the requirements and are now registered to practice forestry under the provisions of the B.C. Foresters Act:Raymond Lowery, B.C. Forest Service, Park's Division, Victoria, B.C.; John G. Y. Murray, Passmore Lumber Co. Ltd., Passmore, B.C.; Michael Stewart, B.C. Forest Service, Research Division, Victoria, B.C.; Philip H. Judd, B.C. Forest Service, Management Plans Division, Victoria, B.C.; Helmut Bradatsch, B.C. Forest Service, Survey's Division, Victoria, B.C.; H. Chris. LangkildeLauesen, B.C. Forest Service, Survey's Division, Victoria, B.C.; Peter Small, B.C. Forest Service, Kamloops, B.C.; William D. Morton, B.C. Forest Service, Survey's Division, Victoria, B.C.; Victor M. Young, Nalos Lumber Co., Vancouver, B.C.; Richard S. Coleman, Dept. of Finance, Timber Appraisal Div.; Victoria, B.C.; Anthony B. Robinson, B.C. Forest Service, Victoria, B.C.; Jan Selsing, B.C. Forest Service, Survey's Division, Victoria, B.C.; Donald H. Baxter, B.C. Forest Service, Clearwater, B.C. 